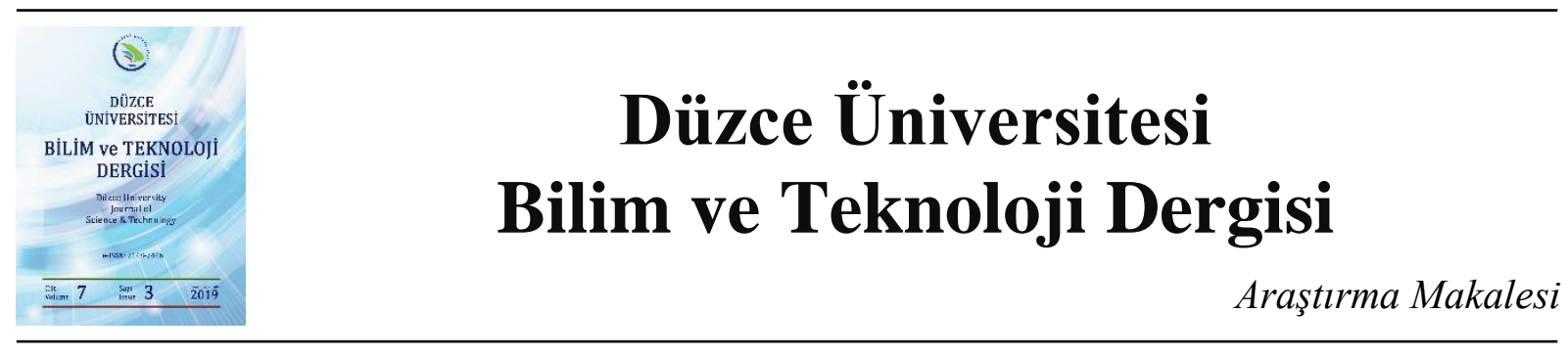

\title{
Orman Ürünleri Sanayinde Toplam Kalite Yönetimi (TKY) Uygulamaları; Düzce İli Örneği
}

\author{
(iD) İdris ALBAYRAK ${ }^{\mathrm{a}}$, iD Derya SEVİM KORKUT ${ }^{\mathrm{b}^{*}}$ \\ ${ }^{a}$ Fen Bilimleri Enstitüsü, Orman Endüstri Mühendisliği ABD Yüksek Lisans Öğrencisi, Düzce, TÜRKIYYE \\ ${ }^{b}$ Orman Endüstri Mühendisliği Bölümü, Orman Fakültesi, Düzce Üniversitesi, Düzce, TÜRKIYE \\ * Sorumlu yazarın e-posta adresi: deryasevimkorkut@duzce.edu.tr \\ DOI : 10.29130/dubited.560903
}

\begin{abstract}
ÖZET
$\mathrm{Bu}$ çalışmada Düzce ilinde faaliyette bulunan orman ürünleri sanayi işletmelerinin Toplam Kalite Yönetimi (TKY) uygulamaları ile ilgili genel durumlarının belirlenmesi amaçlanmıştır. Bu amaçla Düzce'de belirlenen 40 adet orman ürünleri sanayi işletmesi ile yüzyüze görüşme yöntemi ile anket çalışması yapılmıştır. Çalışma sonucunda, işletmelerin \%60'ında kalite kontrol bölümünün bulunduğu, kalite kontrol bölümünde çalışanların \%83,3'ünün kalite ile ilgili eğitim aldıkları belirlenmiştir. Ayrıca İşletmelerin \%37,5'inin TKY çalışmalarından haberdar oldukları, TKY'nin işletmelerin \%42,5'inde uygulandığ 1 sonucuna varılmıştır.
\end{abstract}

Anahtar Kelimeler: Düzce, kalite, orman ürünleri sanayi, toplam kalite yönetimi, TKY.

\section{Total Quality Management (TQM) Applications in Forest Products Industry; Düzce Province Example}

\section{ABSTRACT}

In this study, it is aimed to determine general conditions of Total Quality Management (TQM) applications of forest products industrial enterprises operating in Düzce province. For this purpose, 40 forest products industrial enterprises in Düzce were surveyed by face to face interview method. As a result of the study, it was determined that $60 \%$ of the enterprises had quality control department and $83,3 \%$ of the employees in the quality control department received quality related training. In addition, it was concluded that $37.5 \%$ of enterprises were aware of TQM studies and TQM was applied in $42,5 \%$ of enterprises.

Keywords: Düzce, forest products industry, total quality management, TQM, quality.

Geliş: 06/05/2019, Düzeltme: 23/05/2019, Kabul: 28/05/2019 


\section{GiRis}

$\mathrm{K}_{\mathrm{b}}^{\mathrm{a}}$ alite kavramı yaşamın her aşamasında kullanılmasına rağmen, herkesin genel olarak uzlaşacağı bir kalite tanımı yapılması neredeyse olanaksızdır [1]. Latince "qualis" kelimesinden türetilmiş olup, Latince "gerçekten öyle olmak" anlamındadır [2]. Kalite, bir ürünün ya da hizmetin kullanıma uygunluk derecesi, kullanıcının beklentisini karşılama derecesi olarak tanımlanabilir [3].

Kalite kavramı bir sonucu ifade etmekle birlikte değerlendirmenin bir çıktısı olarak da görülmektedir. Tüketiciler, kalite konusunda belirleyici konumunda olup, işletmelerin temel kaynaklarıdır [4]. Bu nedenle kalite kavramı, işletmelerin müşterilerini memnun etmeye ve işletmelerde çalı̧̧anların "sosyal sorumluluk" bilincinin gelişmesine katkı sağlayan yönetim kavramı ile birlikte anılmaya başlanmıştır. Bunun sonucu olarak Toplam Kalite Yönetimi (TKY) kavramı karşımıza çıkmıştır [5].

TKY müşteri odaklı, sürekli gelişmeyi sağlayan insana değer veren bir yaklaşımdır [6]. Bir kuruluştaki tüm faaliyetlerin sürekli olarak iyileştirilmesi ve tüm çalışanların katılımıyla çalışanlar, müşteriler ve toplumun memnun edilmesiyle karlılığa ulaşılması olarak tanımlanır [5]. Kavramın içerisindeki "toplam" kelimesi, kalitenin tüm süreçlerde herkesin katılımıyla gerçekleşeceğini ifade etmektedir [7]. Herkesin katılımı sadece sürekli gelişim için değil motivasyonu artırması ve eğitici katkısı nedeniyle de önemlidir [8].

TKY'nin amacı, piyasanın ihtiyaçlarına ağırlık verilmesi, tüm alanlarda kalitenin sağlanması, kalite standartlarının oluşturulması, süreçlerin sürekli geliştirilmesi ve iletişimin sağlanmasıdır. TKY'nin bu amaca ulaşabilmesi, işletme çalışanlarının tümünün kalite iyileştirme çalışmalarına gönüllü olarak katılımının sağlanmasına bağlıdır [5].

TKY'nin başarı ile uygulanabilmesi için kritik başarı faktörleri olarak adlandırılan bazı koşulların yerine getirilmesi gerekir. Bu faktörlerin önemlileri; üst yönetimin desteği ve bağlılı̆̆ı, sürekli eğitim ve geliştirme, yönetsel liderlik, kurumsal kültürün değişimi, uygun kurumsal yapı, tüm şirket bazında katılım, tanıma ve ödül sistemlerinin oluşturulması olarak sıralanabilir [7]. TKY'nin uygulanması sonucunda verimlilik, karlılık ve pazar payları artmakta, fire oranları azalmakta, maliyetler düşmekte, yapılan işlem zamanları kısalmakta ve makul kaynak kullanımı sağlanmaktadır [9].

TKY'nin uygulanması sırasında sorunlar da ortaya çıkabilmektedir. Ortaya çıan sorunlar kalite konusunda var olan yanlış düşünceler ve TKY'nin anlaşılması ve uygulanmasında yapıllan yanlışlar ve eksikler olmak üzere iki grupta incelenmektedir. Bu sorunlar TKY'nin işletmelerde etkili bir şekilde çalışmasını engelleyerek başarısız uygulamalara neden olmaktadır. $\mathrm{Bu}$ başarısız uygulamaların maliyetleri artırması ve TKY'nin geçerliliği konusunda güvensizlik yaratması nedeniyle üzerinde durulması önemlidir [10].

$\mathrm{Bu}$ çalışmada orman ürünleri sanayi işletmelerinin TKY uygulamaları ile ilgili genel durumlarının belirlenmesi amaçlanmıştır. Bu amaçla Düzce ilinde orman ürünleri sanayinde faaliyet gösteren işletmeler çalışma kapsamına alınmıştır.

\section{MALZEME VE YÖNTEM}

Çalışmanın amacı doğrultusunda Düzce Ticaret ve Sanayi Odası [11] 2017 yılı verilerine göre Düzce ilinde orman ürünleri sanayinde faaliyet gösteren toplam 60 işletme çalışmanın evrenini oluşturmuş̧tur. 
Evreni temsil edecek örneklem büyüklüğünün belirlenmesinde aşağıdaki formülden yararlanılmıştır [12].

$n=\frac{Z^{2} \cdot N \cdot P \cdot Q}{N \cdot D^{2}+Z^{2} \cdot P \cdot Q}$

n: Minimum örnek büyüklügü̈.

Z: Güven katsayısı (\%95’lik güven için bu katsayı 1,96 alınmıştır)

N: Ana kütle büyüklüğü.

P: Ölçmek istenilen özelliğin ana kütlede bulunma ihtimali (\%50-\%50)

Q: 1-P

D: Kabul edilen örnekleme hatası (Çalışma için \%10'luk bir örnekleme hatası öngörülmüştür)

Formül üzerinde veriler girildiğinde $\% 95$ güven düzeyi ve $\% 10$ hata payı dikkate alınarak 37 işletmeye ulaşılması gerektiği belirlenmiştir. Çalışma kapsamında anket çalışması Mayıs-Aralık 2018 döneminde 45 işletmeye uygulanmıştır. Ancak elde edilen anketlerin incelenmesi sonucunda bazı soruların eksik ya da hatalı cevaplandırılması nedeniyle 5 adet anket değerlendirme dışında tutularak toplam 40 anket değerlendirmeye alınmıştır. Elde edilen veriler SPSS [13] (2003) ortamına aktarılarak istatistik yöntemlerle değerlendirilmiştir.

Çalışmada veri elde etme aracı olarak anket yöntemi kullanılmıştır. Hazırlanan anket formunun oluşturulması aşamasında literatürde yer alan çalışmalar $[1 ; 2 ; 5 ; 6 ; 9 ; 14-21]$, incelenmiş ve çalışma amacına uygun bir anket formu hazırlanmıştır. Anket formu 3 bölümden oluşturulmuştur. Birinci bölümünde; işletmelerin yapısı hakkında veriler elde edilmeye çalışılmıştır. İkinci bölümünde; işletmelerin kalite kontrol faaliyetleri sorgulanmıştır. Üçüncü bölümünde; işletmelerin uyguladıkları TKY faaliyetlerini belirlemeye yönelik sorulara yer verilmiştir.

Araştırmada elde edilen anket verileri SPSS (2003) paket programında tanımlayıcı istatistikler ve güvenilirlik analizleri yapılarak değerlendirilmiştir.

Bu çalışma, Düzce ilinde orman ürünleri sanayinde faaliyet gösteren işletmeler ve hazırlanan anket formundan elde edilen verilerle sınırlıdır. Anket sorularının katılımcılar tarafından doğru anlaşıldığı ve soruların içtenlikle yanıtlandığı varsayılmıştır.

\section{BULGULAR VE TARTIȘMA}

\section{A. GEÇERLILIK VE GÜVENILIRLIK ANALIZII}

Hazırlanan anket formunun faktör modeline uygunluğu konusunda karar verebilmek için Kaiser Meyer Olkin (KMO) Örnekleme Yeterliliği Ölçüsüne bakılmıştır. Anket formundaki tüm yargılar için KMO'nun Örnekleme Yeterliliği Ölçüsü $=0,509$ ve Bartlett'in Küresellik testi $=813,785$ bulunmuştur. Bu sonuçlar veri grubunun faktör analizine uygun olduğunu ve geçerlilik açısından bir sorun teşkil etmediğini göstermektedir. [22]'ye göre KMO ölçüsü 0,5 ve altına düştügünde değişkenlere faktör analizi uygulanması önerilmemektedir. 
Verilerin genel güvenilirlik değeri (Cronbach Alpha Katsayısı) 0,965 olarak belirlenmiştir. Bu sonuç ölçeğin yüksek derecede güvenilirliğe sahip olduğunu göstermektedir. [23]'e göre alfanın 0,40'dan küçük olması ölçeğin güvenilir olmadığını, 0,80-1,0 arası ise yüksek güvenilirliğe karşılık geldiğini göstermektedir.

\section{B. IŞLETME YAPISINA AITT BILGILER}

Katılımc1 işletmelerin faaliyet alanları incelendiğinde; katılımcı işletmelerin \%37,5'inin mobilya, \%20'sinin kereste ve \%20'sinin levha sektöründe faaliyet gösterdikleri belirlenmiştir. Katılımcılar diğer $(\% 22,5)$ seçeneği altında tüfek dipçiği, parke, okul sırası, masif panel, sandalye alanında faaliyet gösterdiklerini belirtmişlerdir (Tablo 1). [18] tarafından Kırklareli, Tekirdağ ve Edirne illerinde orman ürünleri sektöründe faaliyet gösteren işletmeler ile yapılan çalışmada, işletmelerin \%30'unun mobilya, \%16,7'sinin kağıt, \%8,3'ünün levha, \%45'inin ambalaj, parke, palet, kereste, yalıtım malzemesi ve kapı alanında faaliyet gösterdikleri belirtilmiştir. [24] tarafından Batı Karadeniz Bölgesinde orman ürünleri sektöründe faaliyet gösteren işletmeler ile yapılan çalışmada, işletmelerin \%46'sının mobilya, \%30'unun kereste, \%12'sinin levha, \%10'unun kap1 imalatı ve \%2'sinin kâğıt endüstrisi alanında faaliyet gösterdikleri belirtilmiştir.

Tablo 1. İşletmelerin faaliyet alant.

\begin{tabular}{ccc}
\hline Seçenekler & Frekans & Yüzde (\%) \\
\hline Mobilya & 15 & 37,5 \\
Diğer & 9 & 22,5 \\
Kereste & 8 & 20 \\
Levha & 8 & 20 \\
Toplam & 40 & 100 \\
\hline
\end{tabular}

*1: Evet, 2: Hayır

Katılımc1 işletmelerin \%17,5'inin 6-10 yıl arasında, \%20'sinin 11-15 yıl arasında, \%22,5'inin ise 26 yıl ve üzerinde orman ürünleri alanında faaliyet gösterdikleri belirlenmiştir (Tablo 2). [24] tarafından yapılan çalışmada, işletmelerin \%40,8'inin 30 yıldan daha fazla, \%22,4'ünün 6-10 yıl arasında, $\% 8,2$ 'sinin 1-5 yıl arasında orman ürünleri alanında faaliyet gösterdikleri belirtilmiştir.

Tablo 2. İsletmelerin faaliyet yıll.

\begin{tabular}{ccc}
\hline Seçenekler & Frekans & Yüzde (\%) \\
\hline $1-5$ y1l & 4 & 10 \\
$6-10$ y1l & 7 & 17,5 \\
$11-15$ y1l & 8 & 20 \\
$16-20$ y1l & 6 & 15 \\
$21-25$ y1l & 6 & 15 \\
26 y1l ve üzeri & 9 & 22,5 \\
Toplam & 40 & 100 \\
\hline
\end{tabular}

Katılımcı işletmelerin hukuki yapıları incelendiğinde; işletmelerin $\% 52,5$ 'inin anonim şirket, \%37,5'inin limitet şirket, \%7,5'inin şahıs şirketi, \%2,5' inin ise kooperatif olduğu belirlenmiştir.

[21] tarafından Düzce ili orman ürünleri sektöründe faaliyet gösteren işletmelerle yapılan çalışmada, işletmelerin \%54,5'inin anonim şirket, \%36,4'ünün limitet şirket \%9,1'inin şahıs şirketi olduğu 
belirtilmiştir. [25] tarafından Kocaeli ilinde orman ürünleri sektöründe faaliyet gösteren işletmeler ile yapılan çalışmada katılımcı işletmelerin \%30'unun anonim şirket, \%46'sının limitet şirket, \%18'inin şahıs şirketi, \%2'sinin ise adi ortaklık olduğu belirlenmiştir.

Çalışma kapsamında toplam çalışan sayısı dikkate alındığında katılımcı işletmelerde en az 10, en fazla 400 çalışanın olduğu belirlenmiştir. İşletmelerde ortalama çalışan sayısı 71 olarak hesaplanmıştır.

Katılımcı işletmelerin $\% 27,5$ 'i sipariş üretimi, \%12,5'i seri üretim, \%60’1 bazı ürünler için seri bazı ürünler için sipariş tipi üretim yaptıklarını belirtmişlerdir. [18] yaptı̆̆ 1 çalışmasında işletmelerin \%38,3'ünün sipariş üretimi, \%35'inin bazı ürünler için seri bazı ürünler için sipariş üretimi, \%26,7'sinin ise seri üretim yaptığını belirtmiştir. [21]'in çalışmalarında işletmelerin \%24,3'ünün seri üretim, \%21,6'sının sipariş üretimi ve \%54,1'inin bazı ürünler için seri bazı ürünler için sipariş üretimi yaptı̆̆ belirtilmiştir.

\section{ISSLETMELERIN KALITE KONTROL FAALIYETLERI}

Katılımc1 işletmelerin kalite kontrol bölümlerinin varlığ1 sorgulandığında, işletmelerin \%60'ında kalite kontrol bölümünün bulunduğu, \%40'ında ise bulunmadığ 1 belirlenmiştir. [18] çalışmasında işletmelerin \%51,7'sinde kalite kontrol bölümünün bulunduğu, [21]'in çalışmalarında ise işletmelerin \%64,9’unda kalite kontrol bölümünün bulunduğu belirtilmiştir.

Kalite kontrol bölümünde çalışanlara kalite ile ilgili eğitim verilme durumu irdelendiğinde; kalite kontrol bölümünde çalışanların \%83,3'ünün kalite konusunda eğitim aldığı, \%16,7'sinin ise eğitim almadığı belirlenmiştir. Katılımcı işletmeler kalite eğitimlerinin \%62,5 oranında işletme bölüm çalışanları, \%37,5 oranında danışmanlık şirketi tarafından verildiğini belirtmişlerdir.

Katılımcı işletmelerin \%35'inde kalite sorunu yaşandığı belirlenmiştir. İşletmeler yaşadıkları kalite sorunlarını; kalınlık, renk hataları, gönye, üretim hataları, proje hataları olarak belirtmişlerdir. Kalite sorunları yaşayan işletmelerin $\% 57,2$ 'sinin bu sorunları nadiren, $\% 35,7$ 'sinin bazen, $\% 7,1$ 'inin ise her zaman yaşadıkları belirlenmiştir.

\section{ISSLETMELERIN TOPLAM KALITTE YÖNETIMİ ÇALIŞMALARI}

\section{D.1) ISSLETMELERIN TKY'DEN HABERDAR OLMA DURUMU}

Katılımcı işletmelerin TKY çalışmalarından haberdar olma durumları irdelendiğinde; işletmelerin \%37,5'i TKY'den haberdar oldukların1, \%50'si kısmen haberdar olduklarını, \%12,5'i ise haberdar olmadıklarını belirtmişlerdir. Tablo 3'te TKY konusunda bilgi sahibi olan katılımcıların çoğunlukla, "seminerlerden" ve "kitap ve dergilerden" bu bilgiyi edindikleri görülmektedir. [6] tarafından Kocaeli ilinde faaliyet gösteren işletmeler ile yapılan çalışmada katılımcı işletmelerin TKY hakkında bilgi edinme şekillerinin; kitap ve dergiler $(\% 28,4)$, seminerler $(\% 65,7)$, özel kurslar $(\% 44,1)$, üniversite eğitimi $(\% 16,7)$ olduğu belirtilmiştir.

Tablo 3. İşletmelerin TKY hakkında bilgiyi öğrendikleri yerler.

\begin{tabular}{ccc}
\hline Seçenekler & Ortalama* $^{*}$ & Standart sapma \\
\hline Seminerler & 1,4250 & 0,50064 \\
Kitap ve dergi & 1,6500 & 0,48305 \\
Özel kurslar & 1,8750 & 0,33493 \\
Üniversite eğitimi & 1,9250 & 0,26675 \\
\hline
\end{tabular}

*1: Evet, 2: Hayır 
TKY'nin katılımcı işletmelerde uygulanma durumu irdelendiğinde; işletmelerin \%42,5'inde TKY'nin uygulandığı, \%45'inde uygulanmadığı, \%12,5'inde uygulamaya geçiş aşamasında olduğu belirlenmiştir (Tablo 4). [6] Kocaeli ilinde faaliyet gösteren işletmeler ile yaptı̆̆ çalışmasında; katılımcı işletmelerin \%74,5'inde TKY'nin uygulandığını, \%25,5'inde ise TKY'nin uygulamaya geçiş aşamasında olduklarını belirtmiştir. [9] tarafından İstanbul ilinde faaliyet gösteren 5 yıldızlı otel işletmeleri ile yapılan çalışmada, katılımcı işletmelerin tamamında TKY'nin uygulandığı belirtilmiştir.

Tablo 4. TKY'nin uygulanma durumu.

\begin{tabular}{ccc}
\hline Seçenekler & Frekans & Yüzde (\%) \\
\hline Evet uygulanıyor & 17 & 42,5 \\
Hayır uygulanmıyor & 18 & 45 \\
Uygulamaya geçiş aşamasındayız & 11 & 12,5 \\
Toplam & 22 & 100 \\
\hline
\end{tabular}

\section{D.3) TKY UYGULANMAYAN ISSLETMELERDE TKY'Yİ KISITLAYICI ETKENLER}

TKY uygulamayan katılımcı işletmelerde TKY'ye geçişi kısıtlayıcı etkenler arasında en önemli yargıların "strateji eksikliği”" ve "amaçların tanımlanmamış olması" yargılarının olduğu görülmektedir. En az öneme sahip yargılar ise "kaynak yetersizliği” ve "personelde motivasyon eksikliği" yargıları olarak belirlenmiştir (Tablo 5).

Tablo 5. TKY uygulanmayan işletmelerde TKY'ye geçişi kısıtlayıcı etkenler.

\begin{tabular}{ccc}
\hline Seçenekler & Ortalama* $^{*}$ & Standart sapma \\
\hline Strateji eksikliği & 3,2222 & 0,94281 \\
Amaçların tanımlanmamış olması & 3,0556 & 1,05564 \\
Zaman kaybı olarak algılanması & 2,8889 & 0,90025 \\
Personelde eğitim eksikliği & 2,7222 & 1,01782 \\
Talep belirsizliği & 2,7222 & 0,95828 \\
Organizasyon kültürü & 2,6667 & 1,02899 \\
Üst yönetim ve çalışanlar arasındaki iletişim eksikliği & 2,6667 & 0,97014 \\
Uzun vadeli sürdürülebilirlik eksikliği & 2,6111 & 0,84984 \\
Üst yönetim desteğinin eksikliği & 2,5556 & 0,98352 \\
Üretim süresinin belirsizliği & 2,5000 & 1,02899 \\
Girdi kalitesi & 2,5000 & 0,92355 \\
Yüksek fire oranı & 2,4444 & 0,98352 \\
Kaynak yetersizliği & 2,2222 & 0,94281 \\
Personelde motivasyon eksiklĭği & 2,1667 & 0,85749 \\
\hline
\end{tabular}

*1: Kesinlikle katılmıyorum, 2: Katılmıyorum, 3: Kararsızım, 4: Katılıyorum, 5: Kesinlikle katılıyorum

\section{D.4) ISSLETMELERIN TKY'YE BAŞLAMA NEDENLERI}

TKY uygulayan ve TKY uygulamasına geçiş aşamasında olan katılımcı işletmelerin TKY'ye başlama nedenleri arasında en önemli yargıların "işletmenin imajını yükseltmek", "rekabet gücünü artırmak" ve "pazar payını artırmak" yargılarının olduğu görülmektedir. En az öneme sahip yargı ise "kalite ödülü kazanmak" yargısı olarak belirlenmiştir (Tablo 6). [6] Kocaeli ilinde faaliyet gösteren işletmeler ile yaptığı çalışmasında işletmelerin TKY'ye başlama nedenlerini; ürünlerin kalitesini müşterilere 
kanıtlamak $(\% 46,1)$, verimliliği yükseltmek $(\% 22,5)$, müşteri şikayetlerini azaltmak $(\% 19,6)$, firmanın imajını yükseltmek $(\% 9,8)$, kalite ödülünü almak $(\% 2)$ olarak belirtmiştir.

Tablo 6. İsletmelerin TKY'ye başlama nedenleri.

\begin{tabular}{ccc}
\hline Seçenekler & Ortalama $^{*}$ & Standart sapma \\
\hline İşletmenin imajı̈ı yükseltmek & 4,5455 & 0,50965 \\
Rekabet gücünü artırmak & 4,5455 & 0,50965 \\
Pazar payını artırmak & 4,5455 & 0,50965 \\
Misyon/Vizyon/Hedefe katkı sağlamak & 4,5000 & 0,51177 \\
Müşteri memnuniyeti sağlamak & 4,5000 & 0,51177 \\
Ürünlerin kalite düzeylerini artırmak & 4,5000 & 0,51177 \\
Çalışan memnuniyetini sağlamak & 0,4545 & 0,59580 \\
Müş̧teri şikayetlerini azaltmak & 0,4545 & 0,50965 \\
Verimliliği artırmak & 4,4091 & 0,59033 \\
Maliyetleri azaltmak & 4,3636 & 0,65795 \\
Kalite ödülü kazanmak & 4,3636 & 0,58109 \\
Eldeki kaynakların optimum kullanımını săglamak & 4,0000 & 0,87287 \\
\hline
\end{tabular}

*1: Kesinlikle katılmıorum, 2: Katılmıorum, 3: Kararsızım, 4: Katılıyorum, 5: Kesinlikle katılıyorum

\section{D.5) IŞLETMELERIN TKY'YE GEÇIŞTE SORUN YAŞAMA DURUMU}

Katılımcı işletmelerin TKY'ye geçişte sorun yaşama durumları incelendiğinde, işletmelerin \%86,4'ünün TKY'ye geçişte sorun yaşamadıkları, \%13,6'sının ise kısmen sorun yaşadıkları belirlenmiştir. Kısmen sorun yaşadığını belirten katılımcı işletmeler bu sorunları; TKY biriminin oluşturulması, yer temini, test merkezinin oluşturulması şeklinde belirtmişledir.

\section{Işsletmelerin TKY'yi Uygulama Süresi}

Katılımc1 işletmelerde TKY'nin uygulanma süresi irdelendiğinde; işletmelerin \%27,3'ü 1 yıldan daha kısa, \%50'si 6 yıldan daha uzun süredir TKY'yi uyguladıklarını belirtmişlerdir (Tablo 7).

Tablo 7. TKY'nin uygulanma süresi.

\begin{tabular}{ccc}
\hline Seçenekler & Frekans & Yüzde (\%) \\
\hline 1 yıldan daha kısa & 6 & 27,3 \\
1-2 y1l aras1 & 2 & 9,1 \\
3-5 y1l aras1 & 3 & 13,6 \\
6 y1l ve üzeri & 11 & 50 \\
Toplam & 22 & 100 \\
\hline
\end{tabular}

\section{D.6) IŞLETMELERIN TKY'Yİ UYGULAMA SÜRECINDE DANIŞMANLIK HİZMETİ ALMA DURUMU}

Katılımcı işletmelerin TKY'yi uygulama sürecinde danışmanlık hizmeti alma durumu

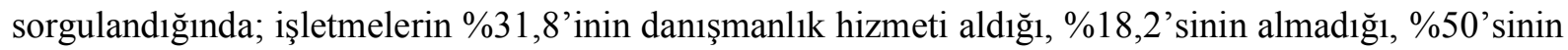
ise kısmen aldığı belirlenmiştir. [6] tarafından Kocaeli ilinde faaliyet gösteren işletmeler ile yapılan çalışmada, katılımcı işletmelerin \%61,8'inin TKY hakkında herhangi bir kuruluştan danışmanlık hizmeti aldığı, \%38,2'sinin ise danışmanlık hizmeti almadıkları belirtilmiştir. 
İşletmelerin TKY'yi uyguladıkları bölümler sorgulandığında katılımcı işletmeler çoğunlukla "bütün bölümler", "üretim" ve "satış" bölümlerinde uygulandığını belirtmişlerdir. Katılımcı işletmelerin TKY'yi "pazarlama" ve "satın alma” bölümlerinde ise daha az uyguladıkları belirlenmiştir (Tablo 8).

Tablo 8. TKY'nin uygulandığı bölümler.

\begin{tabular}{ccc}
\hline Seçenekler & Ortalama* $^{*}$ & Standart sapma \\
\hline Bütün bölümler & 1,4545 & 0,50965 \\
Üretim & 1,6364 & 0,49237 \\
Satış & 1,7273 & 0,45584 \\
Müşteri hizmetleri & 1,7727 & 0,42893 \\
Kalite kontrol & 1,8636 & 0,35125 \\
Pazarlama & 1,9091 & 0,29424 \\
Satın alma & 1,95545 & 0,21320 \\
\hline
\end{tabular}

*1: Evet, 2: Hayır

\section{D.8) ISSLETMELERDE TKY EĞİTIMLERININN DURUMU}

Katılımc1 işletmelerin \%81,8'inde çalışanlara TKY konusunda eğitimler verildiği belirlenmiştir. [17] tarafından Balıkesir ilinde gıda sektöründe faaliyet gösteren işletmelerle yapılan çalışmada, katılımcıların \%43,9'unun TKY konusunda eğitim aldığı, \%56,1'inin eğitim almadığı belirtilmiştir.

Çalışanlara TKY konusunda verilen yıllık eğitimlerin süreleri sorgulandığında ise; katılımcı işletmelerin \%38,9'unda 11-15 saat, \%27,7'sinde 16 saat ve üzerinde eğitim verildiği belirlenmiştir (Tablo 9). [17] tarafindan yapılan çalışmada, katılımcıların \%14,6'sına 1-5 saat arası, \%22'sine \%5-10 saat arası, \%2,4'üne 10-15 saat arası, \%7,3'üne ise 15 saatten fazla eğitim verildiği belirtilmiştir.

Tablo 9. TKY ile ilgili eğitimlerin durumu.

\begin{tabular}{cccc}
\hline & Seçenekler & Frekans & Yüzde (\%) \\
\hline Çalışanlara TKY konusunda & Evet & 18 & 81,8 \\
eğitim verilme durumu & Hayır & 4 & 18,2 \\
& Toplam & 22 & 100 \\
\hline & $1-5$ saat & 3 & 16,7 \\
Çalışanlara TKY konusunda & $6-10$ saat & 3 & 16,7 \\
verilen yıllık eğitim süresi & $11-15$ saat & 7 & 38,9 \\
& 16 saat ve üzeri & 5 & 27,7 \\
& Toplam & 18 & 100 \\
\hline
\end{tabular}

\section{D.9) ISSLETMELERDE UYGULANAN TKY TEKNIKLERI}

Katılımc1 işletmelerde uygulanan TKY teknikleri irdelendiğinde, işletmeler tarafından uygulanan kalite yönetim teknikleri arasında "beyin firtınası" ve "sürekli iyileştirme" tekniklerinin en fazla uygulandığı, "serpilme diyagramı" tekniğinin ise en az uygulandığı belirlenmiştir (Tablo 10). [20] tarafından inşaat sektöründe TKY uygulamalarının incelenmesi üzerine yapılan çalışmada, ankete katılan işletmelerin en çok kullandıkları teknikler; akış diyagramı (\%76), beyin firtınası (\%64), nedensonuç diyagramı $(\% 60)$, pareto analizi $(\% 40)$, histogram $(\% 40)$, kontrol diyagramı $(\% 28)$, çetele diyagramı (\%12), serpilme diyagramı (\%4), nominal grup tekniği (\%4), diğer araç ve teknikler (5 neden analizi, değerlendirme toplantıları vb. -\%12) olarak verilmiştir. 
Tablo 10. İşletmelerde uygulanan TKY teknikleri.

\begin{tabular}{ccc}
\hline Seçenekler & Ortalama* $^{*}$ & Standart sapma \\
\hline Beyin Fırtınası & 4,5556 & 0,85559 \\
Sürekli iyileştirme & 4,3000 & 0,65695 \\
Çetele diyagramı & 3,8750 & 1,35620 \\
Histogram & 3,8000 & 1,13529 \\
Kalite çemberleri & 3,7778 & 0,97183 \\
Neden-Sonuç Diyagramı & 3,7273 & 0,90453 \\
Akış diyagramı & 3,5556 & 0,88192 \\
Nominal grup tekniği & 3,5000 & 1,51186 \\
Kontrol diyagramı & 3,4167 & 1,44338 \\
PUKÖ döngüsü & 3,2857 & 1,25357 \\
Pareto diyagramı & 3,1000 & 0,87560 \\
Serpilme Diyagramı & 1,7500 & 0,50000 \\
\hline
\end{tabular}

*1: Hiç, 2: Nadiren, 3: Bazen, 4: Sık sık, 5: Her zaman

\section{D.10) IŞLETMELERDE TKY UYGULAMALARININ BAŞARI DURUMU}

TKY uygulayan işletmelerde TKY uygulamalarının başarılı olma durumu irdelendiğinde, katılımcı işletmelerin \%40,9'u başarılı olduğunu, \%54,6's1 kısmen başarılı olduğunu, \%4,5'i ise başarılı olmadığını belirtmişlerdir.

TKY uygulayan işletmelerin uyguladıkları TKY'nin başarı oranı incelendiğinde, katılımcı işletmelerin \%68,2'si TKY'nin başarı oranını memnun edici bulurken, \%13,6'sı iyi, \%9,1'i çok iyi, \%9,1'i ise kötü olduğunu belirtmiştir.

\section{SONUC}

Düzce ilinde faaliyette bulunan orman ürünleri endüstri işletmelerinin \%60'ında kalite kontrol bölümünün bulunduğu, kalite kontrol bölümünde çalışanların \%83,3'ünün kalite konusunda eğitim aldığ belirlenmiştir.

Katılımc1 işletmelerin \%37,5'i TKY'den haberdar iken, \%50'si kısmen haberdar durumdadır. TKY katılımcı işletmelerin \%42,5'inde uygulanırken, $\% 12,5$ 'inde ise uygulamaya geçiş aşamasındadır. TKY uygulamayan katılımcı işletmelerde (\%45) TKY'ye geçişi kısıtlayıcı en önemli etkenler arasında "strateji eksikliği” ve "amaçların tanımlanmamış olması" yargılarının olduğu görülmektedir.

Katılımcı işletmelerin; işletmenin imajının yükseltilmesi, rekabet gücünün ve pazar payının artırılması amaçlarıyla TKY'yi uyguladıkları belirlenmiştir. TKY'yi uygulayan katılımcı işletmeler tarafından çalışanlara TKY konusunda eğitim verildiği ve bu eğitimlerin süresinin yıllık 1 saat ile 16 saat üzeri arasında değiştiği belirtilmiştir. TKY uygulayan katılımcı işletmeler tarafından TKY'nin başarı durumu memnun edici olarak belirtilmiştir.

TEȘEKKÜR: Bu çalışma Düzce Üniversitesi Fen Bilimleri Enstitüsü Orman Endüstri Mühendisliği Anabilim Dalı'nda yapılan Yüksek Lisans Tezinden hazırlanmıştır. 


\section{$\underline{\text { V. KAYNAKLAR }}$}

[1] C. Öztürk, "Toplam kalite yönetiminin üretim işletmelerine etkisi bir alan çalışması,” Yüksek lisans tezi, İşletme Anabilim Dalı, Kahramanmaraş Sütçü İmam Üniversitesi, Kahramanmaraş, Türkiye, 2014.

[2] M. Koçyiğit, "Küçük ve orta büyüklükteki işletmelerde (KOBI) toplam kalite yönetimi (TKY) kritik faktörlerinin örgütsel performans üzerine etkileri: İzmir ilindeki gıda işletmelerinde bir uygulama," Yüksek lisans tezi, İşletme Anabilim Dalı, Dumlupınar Üniversitesi, Kütahya, Türkiye, 2010.

[3] K. H. Koç, Kalite Kontrol Ders Notları, İstanbul Üniversitesi Orman Fakültesi Orman Endüstri Mühendisliği Bölümü, İstanbul, Türkiye, 2007.

[4] E. Çapacığlu, "Kamu kuruluşlarında toplam kalite yönetimi," Yüksek lisans tezi, İşletme Yönetimi Anabilim Dalı, İstanbul Arel Üniversitesi, İstanbul, Türkiye, 2017.

[5] İ. Çelik, "Toplam kalite yönetimi (TKY) felsefesine göre; yöneticilerin çalışanlarına ilişsin işlevlerini yerine getirebilme düzeyi," Yüksek lisans tezi, Teknoloji Eğitimi Anabilim Dalı, Marmara Üniversitesi, İstanbul, Türkiye, 2011.

[6] E. Cavlak, "Toplam kalite yönetimi uygulamaları ve Kocaeli ili Gebze ilçesindeki işletmelerin incelenmesi," Yüksek lisans tezi, İşletme Anabilim Dalı, Muğla Üniversitesi, Muğla, Türkiye, 2010.

[7] C. Saçl1, "Toplam kalite yönetiminin verimliliğe etkisi-panel mobilya üreten bir işletmede çerçeve uygulama," Yüksek lisans tezi, Mobilya ve Dekorasyon Eğitimi Anabilim Dalı, Dumlupınar Üniversitesi, Kütahya, Türkiye, 2007.

[8] A. Aydın, "Orman ürünleri sanayi sektöründe toplam kalite yönetimi uygulamalarının çalışan performansı üzerine etkilerinin belirlenmesine yönelik yapısal bir model," Doktora tezi, Orman Endüstri Mühendisliği Anabilim Dalı, Karadeniz Teknik Üniversitesi, Trabzon, Türkiye, 2010.

[9] K. Başkan, “Toplam kalite yönetimi ilkeleri ile konaklama işletmeleri performansı arasındaki ilişkilerin incelenmesi İstanbul ili 5 yıldızlı oteller örneği," Yüksek lisans tezi, Turizm İşletmeciliği ve Otelcilik Anabilim Dalı, Balıkesir Üniversitesi, Balıkesir, Türkiye, 2012.

[10] S. Açı, "Toplam kalite yönetimi ile tam zamanında üretim sisteminin birlikte kullanılması ve bir uygulama," Yüksek lisans tezi, İşletme Anabilim Dalı, Atatürk Üniversitesi, Erzurum, Türkiye, 2006.

[11] Düzce Ticaret ve Sanayi Odas1 (2018, 7 Mart). Düzce Ticaret Odast 2017 yll üye kaylt listesi. [Online]. Erişim: http://www.duzcetso.org.tr/

[12] S. Lemeshow, Jr. D. W. Hosmer, K. Janelle \& S. K. Lwanga, Adequacy of Sample Size in Health Studies. World Healt Organization. Courier International Ltd, Tiptree, Colchester, 1990.

[13] SPSS, Institute Inc., SPSS Base 12.0 User’s Guide, pp. 703, 2003. 
[14] T. Pirecioğlu ve K. H. Koç, "Toplam kalite yönetimine geçiş sürecinde Türkiye mobilya endüstrisinin kalite alt yapıs1," İstanbul Üniversitesi Orman Fakültesi Dergisi, seri. A, c.51, s.2, ss.117-130, 2001.

[15] H. Değerli Özdemir, "Eğitim yönetiminde Toplam kalite yönetimi (İstanbul ili örneği)," Yüksek lisans tezi, Eğitim Yönetimi ve Denetimi Anabilim Dalı, Yeditepe Üniversitesi, İstanbul, Türkiye, 2007.

[16] S. Kutlu, "Sanayi işletmelerinde toplam kalite yönetimi ve ISO uygulamalarının performans üzerine etkisi," Yüksek lisans tezi, İşletme Anabilim Dalı, Dumlupınar Üniversitesi, Kütahya, Türkiye, 2010.

[17] R. Sezen Kışlalığlu, "Toplam kalite yönetiminin üretim planlama/kontrolüne etkisi-Balıkesir ili gıda sektöründe faaliyet gösteren süt ve süt ürünleri işletmelerine ilişkin bir uygulama," Yüksek lisans tezi, İşletme Anabilim Dalı, Çanakkale On Sekiz Mart Üniversitesi, Çanakkale, Türkiye, 2011.

[18] A. Karapınar, "Orman ürünleri endüstrisinde kalite yönetiminin incelenmesi (Tekirdağ, Kırklareli, Edirne örneği)," Yüksek lisans tezi, Orman Endüstri Mühendisliği Anabilim Dalı, Düzce Üniversitesi, Düzce, Türkiye, 2015.

[19] B. Bozkurt Küçük, "Orman ürünleri endüstrisinde toplam verimli bakıma yönelik sektörel alt yapının belirlenmesi, İnegöl örneği," Yüksek lisans tezi, Orman Endüstri Mühendisliği Anabilim Dalı, Düzce Üniversitesi, Düzce, Türkiye, 2016.

[20] A. A. A. Shoshan, "Application of total quality management (TQM) in Turkish construction industry," Yüksek lisans tezi, İnşaat Mühendisliği Anabilim Dalı, Çukurova Üniversitesi, Adana, Türkiye, 2016.

[21] D. Sevim Korkut, M. Saraç, "Orman ürünleri endüstrisinde kalite faaliyetlerinin incelenmesi; Düzce ili örneği,” Düzce Üniversitesi Ormancllık Dergisi, c.12, s.1, ss.40-51, 2016.

[22] Ş. Kalaycı, SPSS Uygulamalı Çok Değişkenli İstatistik Teknikleri, Ankara, Türkiye: Asil Yayın Dağıtım, 2010.

[23] K. Özdamar, Paket Programlar İle İstatiksel Veri Analizi, Kaan Kitabevi, 2002.

[24] M. Çil, "Orman ürünleri sanayinde temiz üretim uygulamaları üzerine bir araştırma, Bat1 Karadeniz bölgesi örneği,”, Yüksek lisans tezi, Orman Endüstri Mühendisliği Anabilim Dalı, Düzce Üniversitesi, Düzce, Türkiye, 2015.

[25] T. Karagöz, "Orman ürünleri sanayi işletmelerinin yapısal analizi: Kocaeli örneği," Yüksek lisans tezi, Orman Endüstri Mühendisliği Anabilim Dalı, Düzce Üniversitesi, Düzce, Türkiye, 2019. 